\title{
MENGIDENTIFIKASI PENCATATAN AKTIVA TETAP PADA SUBAK BABAKAN DAN SUBAK TAMBAHAN
}

\author{
Ni Putu Wila Budiadnyani, Luh Eka Putri Suastini,Pande Kadek Mita Andani, \\ Nyoman Dwi Krisna Yani, Kadek Bayu Wiratama, Wayan Juni Artana
}

Jurusan Akuntansi, Universitas Pendidikan Ganesha, Singaraja, Bali, Indonesia

\begin{abstract}
Abstrak
Penelitin ini untuk mengetahui apakah aktiva tetap yang terdapat di Subak Babakan sudah dilakukan pencatatan dengan benar atau tidak untuk setiap aktivanya dan apakah terdapat permasalahan yang disebabkan oleh tidak dilakukannya pencatatan terhadap aktiva tetap. Jadi penulis disini ingin membandingkan dua subak yang ada di Desa Pakraman Kubutambahan yaitu Subak Babakan dengan Subak Tambahan dalam hal pencatatan aktiva tetapnya dan permasalahan di antara kedua subak tersebut.Dari hasil penelitian Dana yang diperoleh oleh Subak Babakan dan Subak Tambahan yang digunakan untuk membeli peralatan serta membiayai kegiatannya sehari-hari yaitu dana yang berasal dari iuran (peturun) dari masing-masing tuluk atau anggota, bantuan dari dinas pertanian dan dari pemerintah provinsi. Sedangkan pada Subak Tambahan proses pengelolaan dana yang masuk ataupun yang keluar jarang diketahui oleh anggota subak tersebut. Dana tersebut hanya diketaui oleh klian dan pengurus subak saja. Proses pengelolaan dana hanya di pertangguangjawabkan kepada seketaris dan bendahara subak.
\end{abstract}

Kata kunci: Dana, Pecatatan, Subak

\section{Abstract}

This research is to determine whether the fixed assets contained in Subak Babakan have been recorded correctly or not for each of their assets and whether there are problems caused by not recording the fixed assets. So the writer here wants to compare the two subaks in the village of Pakraman Kubutambah namely Subak Babakan with Additional Subak in terms of recording its fixed assets and the problems between the two subaks. From the research results Funds obtained by Babak Subak and Additional Subak are used to purchase equipment and finance its daily activities, i.e. funds derived from contributions (descendants) from each tuluk or member, assistance from the agriculture department and from the provincial government. Whereas in the Additional Subak the process of managing incoming and outgoing funds is rarely known by the members of the subak. These funds are only known by clients and subak management. The process of managing funds is only accounted to by subak secretaries and treasurers.

Keywords : Funds, Notes, Subak

\section{Pendahuluan}

Indonesia merupakan negara agraris dimana hampir sebagian penduduknya bekerja di sektor pertanian. Indonesia sendiri diuntungkan dengan kondisi alamnya yang mendukung kegiatan pertanian tersebut bisa berjalan dengan baik seperti lahannya yang subur, memiliki iklim yang tropis, adanya keberagaman sumber daya alam yang melimpah, sehingga sangat cocok untuk melakukan kegiatan bertani. Indonesia kaya akan potensi alamnya yang dapat dikembangkan baik itu pertanian, pertambangan hingga pariwisatanya. Bali merupakan salah satu pulau di Indonesia yang juga penduduknya sebagian besar bekerja pada sektor pertanian.

Bali terkenal akan daerah pariwisatanya baik di dalam maupun luar negeri, Bali menyajikan objek wisata budaya dan keindahan alamnya yang berada di setiap daerah di Bali. Salah satu hal yang juga menarik dari Bali adalah sistem pertaniannya, selain terdapat persawahan yang berbentuk terasering, salah satu yang terkenal adalah terasering yang berada di Ubud. Terdapat juga sistem pertanian tradisional yang unik yang disebut subak. Subak sendiri merupakan organisasi kemasyarakat yang khusus mengatur tentang 
manajemen atau sistem pengairan/irigasi sawah secara tradisional yang digunakan dalam pertanian di Bali. Karena keunikannya tersebut suatu organisasi internasional yaitu UNESCO menetapkan subak sebagai salah satu warisan budaya dunia pada tanggal 29 Juni 2012 lalu, sehingga sebagai masyarakat Bali haruslah berbangga dan turut melestarikan budaya ini. Keberadaan subak sendiri merupakan manifestasi dari filosofi atau konsep dari Tri Hita Karana. Dalam organisasi subak sendiri semua yang dilakukan yang menyangkut dengan pertanian haruslah secara keputusan bersama sehingga tidak terjadi konflik dan setiap pembagian dalam hal apapun haruslah secara adil. Di Bali terutama di daerah Kabupaten Buleleng yaitu di Desa Pakraman Kubutambahan juga menerapkan sistem subak dalam kegiatan bertaninya, bahkan terdapat lebih dari satu subak yang berada disana. Salah satu subaknya bernama "Subak Babakan".

Di dalam akuntansi sendiri terdapat aktiva tetap baik itu peralatan, mesin, kendaraan maupun yang lainnya, yang bisa mendukung kegiatan usaha berjalan dengan baik yang perlu dilakukan pencatatan, dimana dari kegiatan pencatatan tersebut kita bisa mengetahui berapa harga atau biaya yang diperlukan untuk mendapatkan aktiva tetap tersebut, berapa lama aktiva tersebut bisa dipakai dalam kegiatan operasionalnya. Aktiva tetap sendiri tidak hanya diperlukan dalam perusahaan manufaktur saja tetapi segala usaha pastilah membutuhkan aktiva tetap untuk membantu kegiatan usahanya. Untuk sektor pertanian sendiri juga terdapat beberapa aktiva tetap yang dipakai dalam kegiatan bertani seperti peralatan, di Subak Babakan sendiri salah satu aktiva yang digunakan adalah traktor, mesin air, mesin panen, dan lain-lainnya. Yang jadi permasalahan dalam hal ini adalah apakah aktiva tersebut sudah dilakukan pencatatan atau tidak, karena yang seperti kita ketahui organisasi subak tidak seperti perusahaan yang perlu melakukan pencatatan untuk setiap aktiva yang dimilikinya terutama aktiva tetapnya.

Sebagian besar subak walaupun memiliki aktiva tetap yang sedikit, tetapi nilai dari aktiva tetap tersebut cukup besar dan memiliki umur ekonomis yang cukup panjang. Mungkin tidak semua aktiva tetap yang terdapat pada subak dilakukan pencatatan dan bisa saja tidak dilakukan pencatatan. Terdapat banyak subak yang berada di desa Kubutambahan ini dan kami tidak mengetahui apakah mereka semua melakukan pencatatan terhadap aktiva yang dimilikinya. Namun dalam hal ini kami mengambil dua sampel dari subak yang ada yaitu Subak Babakan dan Subak Tambahan. Disini yang kami ketahui Subak Babakan melakukan pencatatan tentang aktiva tetapnya, sedangkan Subak Tambahan tidak melakukan pencatatan tentang aktiva tetapnya.

Maka dari itu dengan dilakukannya penelitian ini penulis ingin mengetahui apakah aktiva tetap yang terdapat di Subak Babakan sudah dilakukan pencatatan dengan benar atau tidak untuk setiap aktivanya dan apakah terdapat permasalahan yang disebabkan oleh tidak dilakukannya pencatatan terhadap aktiva tetap. Jadi penulis disini ingin membandingkan dua subak yang ada di Desa Pakraman Kubutambahan yaitu Subak Babakan dengan Subak Tambahan dalam hal pencatatan aktiva tetapnya dan permasalahan di antara kedua subak tersebut.

\section{Hasil dan Pembahasan}

\subsection{Pencatatan Aktiva Tetap di Subak Babakan dan Subak Tambahan}

A. Gambaran umum tentang subak di Bali dan khususnya Subak Babakan Dan Subak Tambahan.

Subak adalah organisasi kemasyarakatan yang khusus mengatur sistem pengairan sawah yang digunakan dalam cocok tanam padi di Bali, Indonesia. Subak ini biasanya memiliki pura yang dinamakan Pura Uluncarik, atau Pura Bedugul, yang khusus dibangun oleh para petani dan diperuntukkan bagi dewi kemakmuran dan kesuburan dewi Sri. Sistem pengairan ini diatur oleh seorang pemuka adat yang juga adalah seorang petani di Bali.

Revolusi hijau telah menyebabkan perubahan pada sistem irigasi ini, dengan adanya varietas padi yang baru dan metode yang baru, para petaniharus menanam padi sesering mungkin, dengan mengabaikan kebutuhan petani lainnya. Ini sangatlah berbeda dengan sistem Subak, di mana kebutuhan seluruh petani lebih diutamakan. Metode yang baru pada revolusi hijau menghasilkan pada awalnya hasil yang melimpah, tetapi kemudian 
diikuti dengan kendala-kendala seperti kekurangan air, hama dan polusi akibat pestisida baik di tanah maupun di air. Akhirnya ditemukan bahwa sistem pengairan sawah secara tradisional sangatlah efektif untuk menanggulangi kendala ini.

Subak telah dipelajari oleh Clifford Geertz, sedangkan J. Stephen Lansing telah menarik perhatian umum tentang pentingnya sistem irigasi tradisional. la mempelajari purapura di Bali, terutama yang diperuntukkan bagi pertanian, yang biasa dilupakan oleh orang asing. Pada tahun 1987 Lansing bekerja sama dengan petani-petani Bali untuk mengembangkan model komputer sistem irigasi Subak. Dengan itu ia membuktikan keefektifan Subak serta pentingnya sistem ini. Pada tahun 2012 ini UNESCO, mengakui Subak (Bali Cultur Landscape), sebagai Situs Warisan Dunia,pada sidang pertama yang berlangsung di Saint Petersburg, Rusia.

Subak adalah organisasi kemasyarakatan yang khusus mengatur sistem pengairan sawah yang digunakan dalam cocok tanam padi di Bali, Indonesia. Subak ini biasanya memiliki pura yang dinamakan Pura Uluncarik, atau Pura Bedugul, yang khusus dibangun oleh para petani dan diperuntukkan bagi dewi kemakmuran dan kesuburan dewi Sri. Sistem pengairan ini diatur oleh seorang pemuka adat yang juga adalah seorang petani di Bali.

Sebutan tidak resmi yang dipakai untuk menggambarkan perubahan fundamental dalam pemakaian teknologi budidaya pertanian yang dimulai pada tahun 1950-an hingga 1980-an di banyak negara berkembang, terutama di Asia. Hasil yang nyata adalah tercapainya swasembada (kecukupan penyediaan) sejumlah bahan pangan di beberapa negara yang sebelumnya selalu kekurangan persediaan pangan (pokok), seperti India, Bangladesh, Tiongkok, Vietnam, Thailand, serta Indonesia, untuk menyebut beberapa negara. Norman Borlaug, penerima penghargaan Nobel Perdamaian 1970, adalah orang yang dipandang sebagai konseptor utama gerakan ini. Revolusi hijau mendasarkan diri pada empat pilar penting[1]: penyediaan air melalui sistem irigasi, pemakaian pupuk kimia secara optimal, penerapan pestisida sesuai dengan tingkat serangan organisme pengganggu, dan penggunaan varietas unggul sebagai bahan tanam berkualitas. Melalui penerapan teknologi non-tradisional ini, terjadi peningkatan hasil tanaman pangan berlipat ganda dan memungkinkan penanaman tiga kali dalam setahun untuk padi pada tempat-tempat tertentu, suatu hal yang sebelumnya tidak mungkin terjadi. Revolusi hijau mendapat kritik sejalan dengan meningkatnya kesadaran akan kelestarian lingkungan karena mengakibatkan kerusakan lingkungan yang parah. Oleh para pendukungnya, kerusakan dipandang bukan karena Revolusi Hijau tetapi karena ekses dalam penggunaan teknologi yang tidak memandang kaidah-kaidah yang sudah ditentukan. Kritik lain yang muncul adalah bahwa Revolusi Hijau tidak dapat menjangkau seluruh strata negara berkembang karena ia tidak memberi dampak nyata di Afrika.

Subak adalah suatu masyarakat hukum adat yang memiliki karakteristik sosioagrarisreligius, yang merupakan perkumpulan petani yang mengelola air irigasi di lahan sawah. Pengertian subak seperti itu pada dasarnya dinyataan dalam peraturan-daerah pemerintahdaerah Provinsi Bali No.02/PD/DPRD/I972. Pada perkembanganya ada beberapa tokoh yang memperluas pengertian karakteristik sosio-agraris-religius dalam sistem irigasi subak, dengan menyatakan lebih tepat subak itu disebut berkarakteristik sosio-teknis-religius, karena pengertian teknis cakupannya menjadi lebih luas, termasuk diantaranya teknis pertanian, dan teknis irigasi.

Subak sebagai suatu sistem irigasi merupakan teknologi sepadan yang telah menyatu dengan sosio-kultural masyarakat setempat. Kesepadan teknologi system subak ditunjukkan oleh anggota subak tersebut melalui pemahaman terhadap cara pemanfaatan air irigasi yang berlanadaskan Tri Hita Karana (THK) yang menyatu dengan cara membuat bangunan dan jaringan fisik irigasi, cara mengoperasikan, kordinasi pelaksanaan operasi dan pemeliharaan yang dilakukan oleh pekaseh (ketua subak), bentuk kelembagaan, dan informasi untuk pengelolaannya.

Sistem subak mampu melakukan pengelolaan irigasi dengan dasar-dasar harmoni dan kebersamaan sesuai dengan prinsip konsep THK, dan dengan dasar itu sistem subak mampu mengantisipasi kemungkinan kekurangan air (khususnya pada musim kemarau), 
dengan mengelola pelaksanaan pola tanam sesuai dengan peluang keberhasilannya. Selanjutnya, sistem subak sebagai teknologi sepadan, pada dasarnya memiliki peluang untuk ditransformasi, sejauh nilai-nilai kesepadanan teknologinya dipenuhi.

Revolusi hijau telah menyebabkan perubahan pada sistem irigasi ini, dengan adanya varietas padi yang baru dan metode yang baru, para petani harus menanam padi sesering mungkin, dengan mengabaikan kebutuhan petani lainnya. Ini sangatlah berbeda dengan sistem Subak, di mana kebutuhan seluruh petani lebih diutamakan. Metode yang baru pada revolusi hijau menghasilkan pada awalnya hasil yang melimpah, tetapi kemudian diikuti dengan kendala-kendala seperti kekurangan air, hama dan polusi akibat pestisida baik di tanah maupun di air. Akhirnya ditemukan bahwa sistem pengairan sawah secara tradisional sangatlah efektif untuk menanggulangi kendala ini.

Dalam pengelolaan Irigasi Subak, masyarakat Bali mengusung konsep Tri Hita Karana (THK) yang memiliki Hubungan timbal balik antara Parahyangan yakni Hubungan yang harmonis antara anggota atau karma subak dengan Tuhan Yang Maha Esa, Pawongan Hubungan yang harmonis antara anggota Subaknya dimana yang disebut dengan Krama Subak, Palemahan : Hubungan yang harmonis antara anggota Subak dengan lingkungan atau wilayah irigasi Subaknya.

Tri Hita Karana menunjukkan bahwa dengan menyatunya antar ketiga subsistem dalam sistem irigasi subak, maka secara teoritis konflik antar anggota dalam organisasi subak maupun konflik antar subak yang terkait dalam satu sistem irigasi yang tergabung dalam satu wadah kordinasi akan dapat dihindari. terkaitan antar semua subsistem akan memungkinkan munculnya harmoni dan kebersamaan dalam engelolaan air irigasi dalam sistem irigasi subak yang bersangkutan. Hal itu bisa terjadi karena kemungkinan adanya kebijakan untuk menerima simpangan tertentu sebagai toleransi oleh anggota subak (misalnya, adanya sistem pelampias, dan sistem saling pinjam air irigasi). Di Subak Timbul Baru Kabupaten Gianyar, dilakukan kebijakan sistem pelampias dengan memberikan tambahan air bagi sawah yang ada di hilir pada lokasi-lokasi bangunan-bagi lingkungan lingkungan 4 di jaringan tersier. Besarnya pelampias tergantung dari kesepakatan anggota subak.

Sistem Subak merupakan kelembagaan pengelola irigasi yang sangat terkenal didunia internasional, bukan hanya dikalangan Pakar Irigasi, tetapi dikalangan Pakar Sosial Budaya. Cakupan wawasan subak ternyata jauh lebih luas, termasuk nilai dasar yang terkandung dalam filosofi Subak yang disebut TRI HITA KARANA.

TRI HITA KARANA yang berarti hubungan yang harmonis atau penyebab terwujudnya kesejahteraan hibup yang diwujudkan dalam bentuk:

1) Parahyangan : Hubungan yang harmonis antara anggota atau karma subak dengan Tuhan Yang Maha Esa.

2) Pawongan : Hubungan yang harmonis antara anggota Subaknya dimana yang disebut dengan Krama Subak.

3) Palemahan : Hubungan yang harmonis antara anggota Subak dengan lingkungan atau wilayah irigasi Subaknya

Gambaran Subak Babakan Dan Subak Tambahan

Subak Babakan dan Subak Tambahan berlokasi di desa kubutambahan, Subak Babakan tepatnya berada di dusun kaje kangin sedangkan Subak tambahan berada di dusun kubuanyar. Kedua subak ini dibentuk berdasarkan kesadaran masyarakat setempat untuk memajukan pertanian desa Kubutambahan, mengingat Desa Kubutambahan memiliki potensi pertanian yang cukup menjanjikan. Sumber air irigasi kedua subak ini berasal dari bendungan panti yang berada di desa Bungkulan. Sistem pembagian air di kedua subak ini sama yaitu setiap dua hari sekali namun yang membedakannya adalah untuk Subak Babakan mendapatkan bagian air 3 jam pertuluk, sedangkan Subak Tambahan mendapatkan bagian air 3 sampai 4 jam pertuluk. Luas areal subak Babakan dan subak Tambahan adalah masing masing $38 \mathrm{Ha}$ dan $40 \mathrm{Ha}$, dimana hamparan sawah-sawahnya memiliki topografi yang relatif datar.

Prasarana fisik seperti jalan baik untuk roda empat maupun roda dua dikawasan subak-subak dan daerah sekitarnya relatif bagus seingga menjadi faktor pendukung dalam 
pengembangan agro bisnis. Selain itu, jaringan komunikasi, listrik dan air minum untuk masyarakat desa termasuk petani anggota subak sudah sangat baik. Jumlah anggota Subak Babakan sebanyak 42 orang, sedangkan anggota Subak Tambahan sebanyak 50 orang.

Subak Babakan berdiri sudah lama, sejak adanya subak di Bali dulunya subak ini hanya bertujuan untuk mengatur irigrasi perairan yang ada. Dulu Subak ini Hanya mengandalkan mata air atau air yang mengalir dari bendungan panti untuk mengairi sawah dari petakan anggota subak, Tetapi semakin berkembangnya informasi dan teknologi subak ini berkembang begitu pesat, hingga sekarang subak ini tidak lagi mengairi tulukan sawahnya dengan mengandalkan air yang berasal dari bendungan panti saja tetapi pada masing-masing tulukan sawah sudah mempunyai subur yang kedalamnya rata-rata 13 meter. Tetapi para anggota Subak Babakan harus mengeluarkan biaya kembali untuk membeli bahan bakar mesin air tersebut. Subak Babakan ini dulunya hanya beranggotakan 8 orang tetapi seiring waktu Subak Babakan ini sekarang Beranggotakan 48 orang. Subak Babakan dulunya tidak mempunyai stuktur organisasi dan pembagian tugas yang sesuai dengan stuktur organisasi, tetapi sekarang Subak Babakan ini memiliki pembagian tugas yang sesuai dan stuktur organisasi yang sesuai.

Subak Tambahan lebih awal berdiri dibandingkan Subak Babakan. Subak Tambahan letaknya sangat Strategis dibandingkan dengan Subak yang lain yang ada di desa kubutambahan. Subak Tambahan dari dulu sampai sekarang masih mengandalkan air bendungan panti untuk system irigrasinya. Subak Tambahan dulunya beranggotakan 10 orang dan sekarang Subak Tambahan ini beranggota 50 orang. Subak Tambahan dulunya tidak mempunyai stuktur organisasi tetapi sekarang mempunyai struktur organisasi yang kurang sesuai dengan pembagian tugasnya. Subak Tambahan sekarang mengikuti banyak kegiatan lomba yang diselenggarakan ditingkat kecamatan maupun kabupaten Subak Tambahan sekarang tarus diberikan dana dari pemerintah provensi, kabupaten maupun pemerintah desa setempat. Subak Tambahan lebih makmur dibandingkan subak yang lain yang ada di desa Kubutambahan, karena Subak Tambahan selalu diberikan dana kepada pemerintah desa setempat.

B. Struktur organisasi pada Subak Babakan yaitu ;

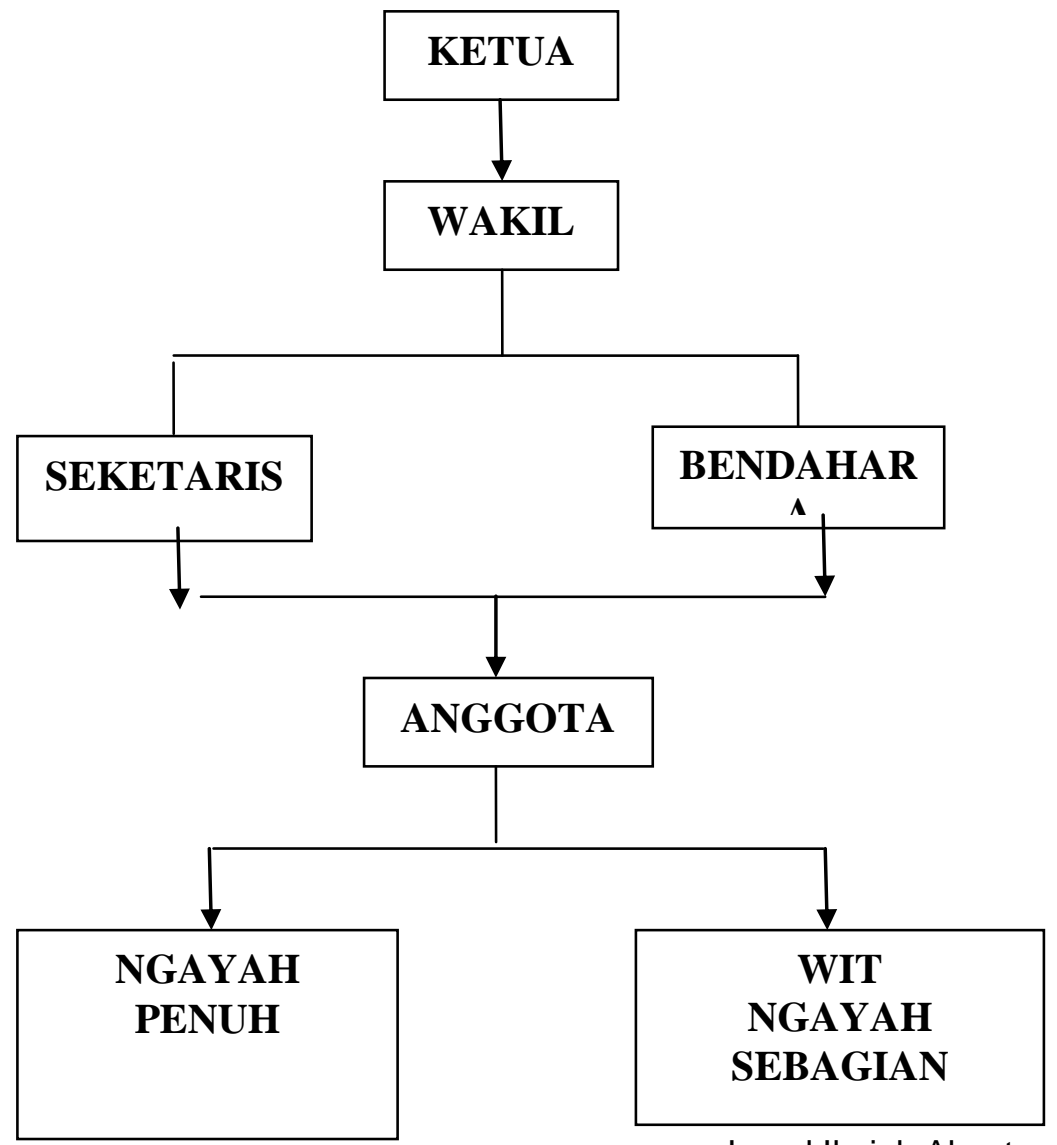

Jurnal IImiah Akuntansi danHumanika |5 


\section{STRUKTUR ORGANISASI DI SUBAK TAMBAHAN}

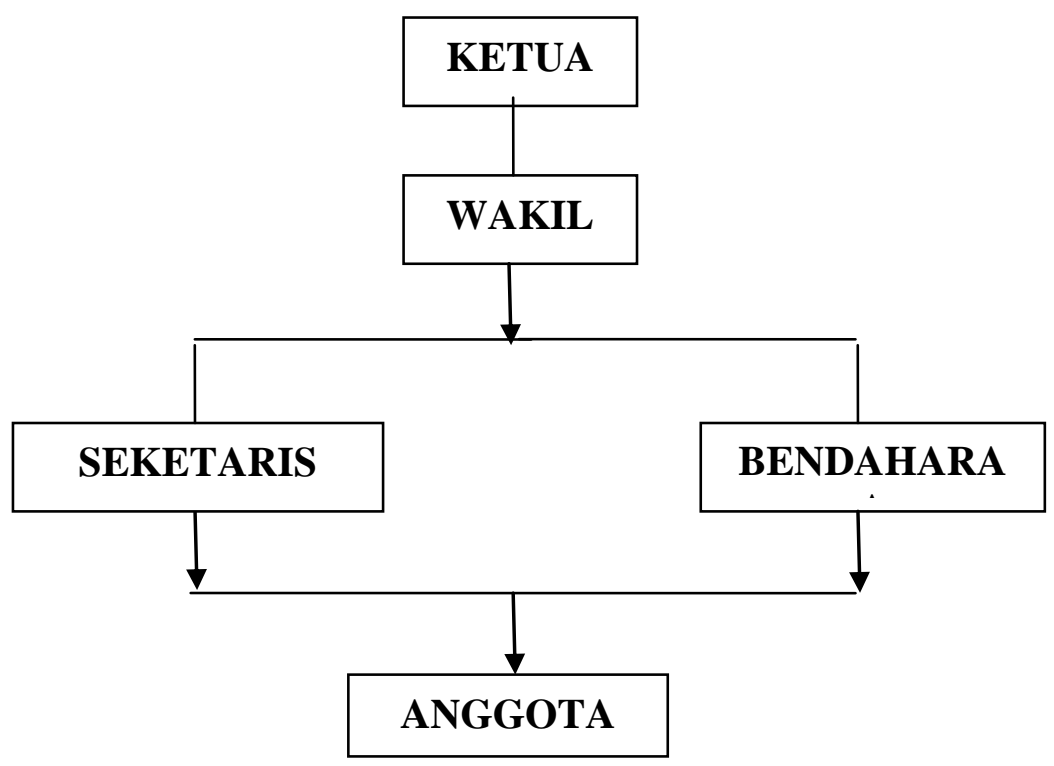

C. Sumber Dana

Sumber dana bisa berasal darimana pun baik itu dengan meminjam, diberikan secara sukarela atau dengan menghimpun dan sendiri. Adapun asal dana yang diperoleh oleh Subak Babakan dan Subak Tambahan yang digunakan untuk membeli peralatan serta membiayai kegiatannya sehari-hari yaitu dana yang berasal dari iuran (peturun) dari masingmasing tuluk atau anggota, bantuan dari dinas pertanian dan dari pemerintah provinsi. Adapun beberapa aktiva tetap yang dimiliki baik dengan membeli maupun diberikan pemerintah kepada krama Subak Babakan yaitu :

1. Traktor

2. Mesin air

3. Mesin Panen

4. Tempat sampah

5. Alat Pertanian lainnya.

1. Traktor.

Sedangkan aktiva tetap yang dimiliki oleh krama Subak Tambahan yaitu :

2. Mesin air

3. Mesin Panen.

4. Mobil Pick-up.

5. Alat pertanian lainnya.

D. Proses Pengelolaan Keuangan

Dalam proses pengelolaan keuangan untuk Subak Babakan ini di ketahui oleh semua pengurus dan para anggota di subak tersebut. Proses pengelolaan keuangan di subak ini merupakan tanggung jawab dari bendahara Subak Babakan. Bendahara subak bertangguang jawab untuk melaporkan segala bentuk penerimaan ataupun pengeluaran yang diperlukan subak, kepada semua anggota Subak Babakan. Laporan pertanggungjawaban merupakan suatu bentuk kewajiban yang tidak dapat dipisahkan dari proses pengelolaan sumber daya suatu organisasi. Salah satu bentuk pertanggung jawabannya adalah dalam hal pengelolaan keuangan. Pertanggungjawaban pengelolaan keuangan ini merupakan suatu bentuk responsibility dari pihak yang bertugas untuk mengelola keuangan kepada pihak-pihak yang memberikan tugas tersebut. Hasilnya nanti berupa laporan dana, dimana laopran dani ini akan di sampaikan kepada semua anggota subak saat setiap diadakannya rapat subak. Subak Babakan mengadakan suatu rapat atau sering disebut paruman ini setiap hari raya tumpek atau diadakan sebulan sekali. Dalam rapat ini para klian subak (pengurus subak) memaparkan apa saja yang menjadi 
permasalahan dan juga apa saja yang menjadi hambatan dalam kegiatan sehari-hari di Subak Babakan ini. Selain itu dalam rapat ini para klian subak juga akan menjelaskan atau menerangkan pengeluaran atau penerimaan apa saja yang masuk menjadi dana subak pada setiap kegiatan yang dilakukan Subak Babakan ini.

Sedangkan untuk Subak Tambahan sendiri dalam proses pengelolaan dananya yang masuk ataupun yang dikeluarkan untuk kegiatan sehari-hari subak jarang diketahui oleh para anggota subak tersebut. Dana yang masuk maupun keluar tersebut hanya diketahui oleh para klian dan pengurus dari Subak Tambahan saja. Untuk proses pengelolaan dana subaknya sendiri hanya di pertangguangjawabkan oleh seketaris dan bendahara subak saja. Subak ini tidak melakukan pencatatan transaksi penerimaan ataupun pengeluaran dananya. Tetapi Subak Tambahan dikenal lebih kaya dan makmur secara material dibandingkan dengan Subak Babakan maupun subak lainnya. Hal ini dikarenakan hanya Subak Tambahan saja yang mendapat bantuan dana yang berasal dari Desa Pakraman Kubutambahan, sehingga subak ini tidak mengadakan pungutan dana iuran (peturunan) kepada para anggota subaknya.

E. Cara Pengelolaan Aktiva Tetap

Dalam hal pengelolaan aktiva tetap yang dimiliki Subak Babakan ini adalah pengelolaannya dengan cara bergilir di masing-masing tulukan (pemilik sawah) dan cara pengecekan untuk peralatan yang digunakan tersebut tergantung dari pemakaian dari masing-masing tulukan yang memakainnya. Untuk aktiva tetapnya yang dimiliki Subak Babakan seperti traktor, mesin air/pompa air, mesin panen padi dan peralatan pertanian lainnya, Subak Babakan ini melakukan pencatatan, namun masih kurang atau belum sesuai dengan pencatatan dalam akuntansi yang semestinya, hal ini dikarenakan kurangnya pengetahuan para anggota didalam melakukan pencatatan aktiva tetap sebagaimana mestinya. Oleh sebab itu tidak dilakukannya pencatatan aktiva tetap secara akuntansi terhadap aktiva tetap yang dimiliki ini tidak bisa diketahui masa pemanfaatannya dan berapa jumlah umur ekonomisnya dari masing-masing aktiva tetap tersebut. Subak Babakan selain mencatat aktiva tetap, mereka juga mencatat dana atau sumbangan yang menjadi pemasukan dan pengeluaran yang terjadi pada saat pelaksanaan kegiatan tertentu. Subak babakan ini juga mencatat transaksi yang terjadi misalnya pada saat penerimaan bantuan dari pemerintah ataupun anggota subak ini dan pengeluaran yang terjadi pada saat upacara atau acara subak tersebut. Pencatatan transaksi disubak ini dikatakan lebih bagus dibandingkan dengan Subak Tambahan.

Sedangkan dalam pengelolaan peralatan pada Subak Tambahan adalah dengan cara, siapa yang paling dulu meminjam aktiva tetap atau peralatan maupun mesin tersebut dialah yang akan mendapatkan bagian pertama yang boleh meminjam dan menggunakannya, berbeda halnya dengan Subak Babakan yang pengelolaan aktiva tetapnya dilakukan secara bergiliran untuk setiap anggotanya. Pengecekan peralatan tidak dilakukan di masing masing tulukan melainkan di kantor subak tersebut. Untuk pencatatan aktiva tetap seperti traktor, mobil, mesin padi dan peralatan pertanian lainnya tidak dilakukan pencatatan baik secara akuntansi maupun pencatatan biasa seperti subak lain pada umumnya karena anggota dari subak Tambahan tidak memiliki pengetahuan yang memadai untuk melakukan pencatatan aktiva tetapnya. Karena rata-rata pendidikan yang dimiliki para anggota dari Subak Tambahan adalah umumnya dari SD sampai SMP. Subak Tambahan ini juga jarang mengadakan rapat atau pertemuan seperti yang dilakukan Subak Babakan, tetapi Subak Tambahan hanya mengadakan paruman (rapat) ini ketika menjelang diadakannya suatu kegiatan saja sehingga tidak bisa saling bertukar pikiran tentang permasalahan yang sedang dihadapi subak ini. Dalam pertemuannya Subak Tambahan ini hanyalah untuk membahas apa saja yang akan dilaksanakan nantinya pada kegiatan tersebut dan tidak ada hal yang membahas tentang dana yang keluar ataupun dana yang masuk ataupun bagaimana dana yang ada tersebut dikelola oleh pengurus. Subak Tambahan ini berbeda dengan subaksubak yang lainnya, perbedaannya adalah subak ini mengadakan rapat tahunan dimana pada rapat ini akan dijelaskan ataupun dipaparkan apa saja pengeluaran atu pemasukan dalam subak Tambahan ini namun subak ini tidak mencatat transaki yang terjadi dan subak 
ini tidak memiliki buku inventaris atau buku yang digunakan untuk mencatat apa saja barang-barang yang dimiliki.

F. Pencatatan Aktiva Tetap

Pencatatan terhadap aktiva tetap pada Subak Babakan ini memang sudah dilakukan tetapi pencatatannya tidak seperti pencatatan dalam akuntansi yang seharusnya, selain itu pencatatan terhadap aktiva tetapnya ini hanya dilakukan saat awal penerimaan atau saat aktiva tetap tersebut telah diperoleh pihak subak saja sehingga kita tidak mengetahui dengan pasti berapa jumlah penyusutan dan berapa umur ekonomis dari setiap aktiva tetapnya Subak Babakan ini. Walaupun pencatatan aktiva tetapnya hanya dilakukan saat pembelian awalnya saja tetapi untuk perbaikan atau perawatan terhadap peralatan yang dimiliki mereka melakukan pencatatannya secara sederhana saja.

Sedangkan pada Subak Tambahan sendiri sama sekali tidak melakukan pencatatan terhadap aktiva tetap yang dimilikinya, hal ini dikarenakan subak ini tidak membeli aktiva tetapnya sendiri melainkan didapat lewat sumbangan atau hibah yang diberika oleh pemerintah setempat kepada Subak Tambahan ini, sehingga saat perolehan aktiva tetapnya tidak dilakukan pencatatan, baik pencatatan secara akuntansi maupun pencatatan dengan cara biasa.

Antara Subak Babakan dan Subak Tambahan ini mereka sama-sama memiliki kemauan untuk melakukan perubahan yaitu agar bisa melakukan pencatatan dengan sistem akuntansi yang berlaku tetapi karena kendala kemampuan dari anggotanya yang dimiliki masih kurang sehingga untuk bisa menerapkan sistem pencatatan akuntansi tersebut masih dirasa cukup sulit, apalagi jenjang pendidikan yang dimiliki oleh anggotanya yang tidak terlalu tinggi itu menjadi sebuah kendala dalam perubahan tersebut. Selain itu tidak adanya sosialisai dari pihak-pihak luar yang lebih memiliki kemapuan dalam bidang akuntansi juga menjadi penghambat.

\subsection{Permasalahan Yang Terjadi Di Subak Babakan dan Subak Tambahan}

Dalam menjalankan setiap kegiatannya di organisasi seperti subak pastilah tidak selalu berjalan lancar tentu ada saja masalah yang terjadi baik itu permasalahn yang berasal dari dalam maupun luar organisasi. Adapun beberapa permasalahan atau hambatan yang di hadapi oleh Subak Babakan ini yaitu, sebagai berikut:

1. Masih minimnya jenjang pendidikan dari para anggota Subak Babakan sehingga perubahan terhadap organisasi tidak terlalu banyak.

2. Kurangnya pengetahuan didalam pencatatan aktiva tetap oleh para anggota Subak Babakan.

3. Kurangnya pengetahuan anggota subak terhadap organisasinya sehingga keterlibatan setiap anggota masih kurang.

4. Kurangnya sosialisasi tentang organisasinya subak kepada anggota maupun ketua subak.

5. Kurangnya partisipasi anggota dalam membantu memajukan Subak Babakan.

6. Dikarenakan lokasi sawah yang jauh dari sumber air atau Bendungan Panti, dalam irigasinya subak ini hanya mengandalkan giliran air yang diterima dan air sumur yang ada dimasing-masing tulukan sawah sehingga dana yang dikeluarkan untuk mengairi sawah lebih besar terutama untuk membeli bahan bakar dalam mengoprasikan pompa air.

7. Tidak adanya saluran dana dari desa Kubutambahan sehingga dana yang ada hanya berasal dari anggotanya saja.

Adapun juga permasalahan pada Subak Tambahan, yaitu:

1. Pengetahuan yang masih kurang dari para anggota subaknya apalagi pengetahuan tentang pencatatan aktivanya.

2. Tidak adanya sosialisasi bagi para anggota dari pihak luar mengenai organisasi subaknya.

3. Jika terjadi kerusakan pada aktiva tetap yang dimiliki maka pihak yang bertanggungjawab adalah pihak yang sedang menggunakan bukan menjadi tanggungan semua anggotanya, ini berarti semua biaya yang dikeluarkan berasal dari dana pribadi pihak yang menggunakan aktiva tersebut. 
4. Sama halnya seperti pernyataan diatas, untuk biaya perbaikan dan perawatan aktiva tetapnya sendiri yang dimiliki, biayanya bukan ditanggung bersama melainkan menjadi tanggungjawab masing-masing anggota yang sedang menggunakannya dimana dana yang digunakan juga dana pribadi bukan anggota.

5. Komunikasi yang kurang baik antar anggota subak, sehingga sering terjadi kesalahpahaman antar anggota dan tidak adanya kekompakan dari para anggotanya.

6. Tidak diadakannya rapat atau pertemuan antara anggota dan pengurus mengakibatkan komunikasi yang kurang baik.

7. Irigasi air hanya mengandalkan air dari Bendungan Panti karena hal ini dikarenakan subak ini tidak memiliki sumur yang terdapat dimasing-masing tulukan.

\section{Simpulan dan Saran}

Subak adalah organisasi kemasyarakatan yang khusus mengatur sistem pengairan sawah yang digunakan dalam cocok tanam padi di Bali, Indonesia. Subak ini biasanya memiliki pura yang dinamakan Pura Uluncarik, atau Pura Bedugul, yang khusus dibangun oleh para petani dan diperuntukkan bagi dewi kemakmuran dan kesuburan dewi Sri. Sistem pengairan ini diatur oleh seorang pemuka adat yang juga adalah seorang petani di Bali. Dalam pengelolaan Irigasi Subak, masyarakat Bali mengusung konsep Tri Hita Karana (THK) yang memiliki Hubungan timbal balik antara Parahyangan yakni Hubungan yang harmonis antara anggota atau karma subak dengan Tuhan Yang Maha Esa, Pawongan Hubungan yang harmonis antara anggota Subaknya dimana yang disebut dengan Krama Subak, Palemahan: Hubungan yang harmonis antara anggota Subak dengan lingkungan atau wilayah irigasi Subaknya. Sistem Subak merupakan kelembagaan pengelola irigasi yang sangat terkenal didunia internasional, bukan hanya dikalangan Pakar Irigasi, tetapi dikalangan Pakar Sosial Budaya. Cakupan wawasan subak ternyata jauh lebih luas, termasuk nilai dasar yang terkandung dalam filosofi Subak yang disebut TRI HITA KARANA.

Subak Babakan dan Subak Tambahan berlokasi di desa Kubutambahan, Subak Babakan tepatnya berada di dusun Kaje Kangin sedangkan Subak tambahan berada di dusun Kubuanyar. Kedua subak ini dibentuk berdasarkan kesadaran masyarakat setempat untuk memajukan pertanian desa Kubutambahan, mengingat Desa Kubutambahan memiliki potensi pertanian yang cukup menjanjikan. Untuk Subak Babakan sendiri berdiri sudah lama, sejak adanya subak di Bali dulunya subak ini hanya bertujuan untuk mengatur irigrasi perairan yang ada. Dulu Subak ini Hanya mengandalkan mata air atau air yang mengalir dari bendungan panti untuk mengairi sawah dari petakan anggota subak, Tetapi semakin berkembangnya informasi dan teknologi subak ini berkembang begitu pesat, hingga sekarang subak ini tidak lagi mengairi tulukan sawahnya dengan mengandalkan air yang berasal dari bendungan panti saja tetapi pada masing-masing tulukan sawah sudah mempunyai subur yang kedalamnya rata-rata 13 meter. Sedangkan Subak Tambahan lebih awal berdiri dibandingkan Subak Babakan. Subak Tambahan letaknya sangat Strategis dibandingkan dengan Subak yang lain yang ada di desa kubutambahan. Subak Tambahan dari dulu sampai sekarang masih mengandalkan air bendungan panti untuk system irigrasinya.

Adapun asal dana yang diperoleh oleh Subak Babakan dan Subak Tambahan yang digunakan untuk membeli peralatan serta membiayai kegiatannya sehari-hari yaitu dana yang berasal dari iuran (peturun) dari masing-masing tuluk atau anggota, bantuan dari dinas pertanian dan dari pemerintah provinsi.

Proses pengelolaan keuangan dalam Subak Babakan di ketahui oleh semua pengurus dan anggota di subak tersebut. Proses pengelolaan keuangan di subak ini merupakan tanggung jawab dari bendahara Subak Babakan. Bendahara subak bertangguang jawab untuk melaporkan segala bentuk penerimaan ataupun pengeluaran dana subak, kepada semua anggota Subak Babakan. Laporan dana ini akan di sampaikan setiap adanya rapat subak. Sedangkan pada Subak Tambahan proses pengelolaan dana yang masuk ataupun yang keluar jarang diketahui oleh anggota subak tersebut. Dana tersebut hanya diketaui oleh klian dan pengurus subak saja. Proses pengelolaan dana hanya di 
pertangguangjawabkan kepada seketaris dan bendahara subak. Subak ini tidak mencatat transaksi yang masuk atau yang keluar.

Pengelolaan peralatan yang dimiliki Subak Babakan adalah dengan cara bergilir di masing masing tulukan (pemilik sawah) dan cara pengecekan peralatan tersebut tergantung dari pemakaian dari masing-masing tulukan yang memakainnya. Subak Babakan melakukan pencatatan, namun masih kurang sesuai dengan pencatatan dalam akuntansi, karena kurangnya pengetahuan didalam melakukan pencatatan aktiva tetap. Subak Babakan selain mencatat aktiva tetap, mereka juga mencatat dana atau sumbangan yang masuk dan pengeluaran yang terjadi pada event tertentu. Subak babakan ini juga mencatat transaksi yang terjadi misalnya pada saat penerimaan bantuan dari pemerintah ataupun anggota subak ini dan pengeluaran yang terjadi pada saat upacara atau acara subak tersebut. Sedangkan pengelolaan peralatan pada Subak Tambahan adalah dengan cara siapa yang paling dulu meminjam aktiva tersebut dialah yang mendapat bagian pertama, berbeda dengan Subak Babakan yang dilakukan secara bergiliran. Pengecekan peralatan tidak dilakukan di masing-masing tulukan melainkan di kantor subak tersebut. Untuk pencatatan aktiva tetap seperti traktor, mobil, mesin padi tidak dilakukan pencatatan seperti subak lain pada umumnya karena anggota dari subak Tambahan tidak memiliki pengetahuan yang memadai untuk mencatat aktiva tetap.

Pencatatan terhadap aktiva tetap pada Subak Babakan memang dilakukan tetapi tidak seperti pencatatan dalam akuntansi, pencatatan terhadap aktiva tetapnya hanya dilakukan saat awal penerimaan atau saat aktiva tetap itu diperoleh saja sehingga berapa jumlah penyusutan dan umur ekonomisnya tidak diketahui. Perbaikan atau perawatan terhadap peralatan yang dimiliki mereka melakukan pencatatan secara sederhana. Sedangkan pada Subak Tambahan sendiri sama sekali tidak melakukan pencatatan hal ini dikarenakan subak ini tidak membeli aktiva tetapnya sendiri, sehingga tidak dilakukan pencatatan baik secara akuntansi maupun pencatatan biasa.

Adapun beberapa permasalahan atau hambatan yang di hadapi oleh Subak Babakan ini yaitu, sebagai berikut: Minimnya jenjang pendidikan dari para anggota Subak Babakan, Kurangnya pengetahuan didalam pencatatan aktiva tetap oleh para anggota Subak Babakan, Kurangnya pengetahuan anggota subak terhadap organisasinya, Kurangnya sosialisasi tentang organisasinya, Kurangnya partisipasi anggota dalam membantu memajukan Subak Babakan, Dikarenakan jauh dari sumber air atau Bendungan Panti. Sedangkan permasalahan pada Subak Tambahan diantaranya, yaitu Pengetahuan yang masih kurang dari para anggota subaknya, Tidak adanya sosialisasi mengenai organisasi subak, Jika terjadi kerusakan pada aktiva tetap yang dimiliki maka pihak yang bertanggungjawab adalah pihak yang sedang memakainya bukan menjadi tanggungan semua anggotanya, Biaya Komunikasi yang kurang baik antar anggota subak, Irigasi air hanya mengandalkan air dari Bendungan Panti karena tidak memiliki sumur dimasingmasing tulukan.

Saran yang bisa kami berikan kepada Subak Babakan adalah anggota-anggotanya harus gencar melakukan penyuluhan dan sosialisasi tentang organiasinya, supaya masyarakat kubutambahan maupun dari pihak pemerintah dapat sepenuhnya mengetahui apa saja keunggulan subak, dan apa saja kekurangan dari subak babakan. Subak Babakan lebih gencar melakukan sosialisasi dan menyampaikan keperluan apa saja yang dibutuhkan oleh subak Babakan kepada pemerintah untuk kemajuan dari subak tersebut. Dan juga berbicara mengenai pendidikan ataupun pengetahua tentang ilmu kuntansi khususnya mengenai aktiva tetap, para anggota harus belajar di public ataupun bertanya kepada orang yang lebih mengetahui tentang ilmu akuntansi khususnya tentang aktiva tetap karena itu bisa mereka pelajari dengan mempraktekkan langsung di subak mereka. Sedangkan saran untuk Subak Tambahan adalah hampir sama seperti subak Babakan yaitu anggota dari Subak Tambahan harus gencar melakukan penyuluhan dan sosialisasi mengenai subak Tambahan, itu bertujuan supaya masyarakat dan pemerintah lebih luas mengetahui tentang subak Tambahan, hal positifnya juga subak Tambahan akan mendapatkan bantuan baik dari material maupun non material dari masyarakat kubutambahan maupun dari pemerintah. Mengingat Subak merupakan organisasi penting 
yang berada di Kubutambahan untuk kemajuan Pertanian desa Kubutambahan. Selain itu saran untuk kemajuan Subak Tambahan adalah megingat ini merupakan sebuah organisasi jadi kerjasama antar anggota subak haruslah senantiasa ditumbuhkan pada diri dari setiap anggota subak, apapun kekurangan ataupun masalah yang dihadapi dari Subak Tambahan hendaknya diselesaikan bersama dan ditanggung bersama dan menjalin komunikasi yang baik di sesama anggota, tidak baik jika berjalan sendiri-sendiri sehingga jalannya kegiatan subak bisa berjalan dengan baik. Ini juga kunci maju tidaknya sebuah subak, terutama pada Subak Tambahan.

Selain saran bagi kedua subak tersebut adapun saran kami bagi Pemerintah Provinsi ataupun Pemerintah desa Kubutambahan adalah pemerintah harus lebih memperhatikan kemajuan dari subak-subak yang berada di setiap wilayah di Bali Khususnya juga yang berada di desa Kubutambahan. Mengingat subak merupakan organisasi yang sangat penting untuk kemajuan pertanian di Kubutambahan khususnya di Bali pada umunya. Pertanian bukan hanya sebagai mata pencarian dari masyarakat, namun juga menarik wisatawan untuk datang ke Bali. Pemerintah di desa kubutambahan hendaknya menyamaratakan anggaran yang diberikan tidak hanya pada satu subak saja melainkan pada semua subak yang ada di desa Kubutambahan, agar tidak adanya kecemburuan sosial pada subak-subak lainnya. Pemerintah desa Kubutambahan hendaknya memberikan sosialisasi tentang pengetahuan cara pencatatan yang berdasarkan akuntansi maupun sosialisasi yang berkaitan dengan subak.

\section{DAFTAR PUSTAKA}

Made Aristia Prayudi dan Komang Adi Kurniawan Saputra. 2016. Akuntansi Pemerintahan. Singaraja: Istiqlal Publishing Group

Bersumber dari wawancara di Kantor Subak Babakan dan Subak Tambahan desa Kubutambahan

http://www.id.baliglory.com/2016/04/subak-bali.html

http://wisatabaliutara.com/2016/04/subak-bali.html/ 